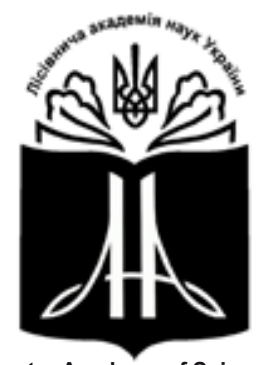

Forestry Academy of Sciences of Ukraine

Наукові праці Лісівничої академії наук України Proceedings of the Forestry Academy of Sciences of Ukraine

http://fasu.nltu.edu.ua https://doi.org/10.15421/411819

Article received 2018.06.17

Article accepted 2018.10.25
ISSN 1991-606X print

ISSN 2616-5015 online

(a) $\triangle$ Correspondence author

Petro Lakyda

lakyda@nubip.edu.ua

Heroyiv Oborony st., 15, Kyiv, 03041, Ukraine

УДК 630*62:57:630*17:582.632.1

\title{
Біотична продуктивність лісів Національного природного парку «Голосіївський»
}

\author{
П.І. Лакида', Б.В. Дубровець²
}

За результатами проведених досліджень наведено структуру $i$ загальні обсяги фітомаси та депонованого в ній вуглеиңю деревостанів Національного природного парку «Голосї̈вський». Розрахунок біотичної продуктивності деревостанів Парку здійснювали окремо для кожного таксаиійного виділу на основі бази даних лісовпорядкування на 2010 р., яка містить дані 1866 виділів. Під час розрахунку обсягів фітомаси деревостанів Парку використано розроблені раніше регресійні рівняння конверсійних коефіиієнтів, щзо зв'язують фітомасу насадження за фракиіями з таксачійними показниками для таких деревних видів, як сосна звичайна, дуб звичайний, граб звичайний та вільха клейка. Вміст депонованого вуглеию деревостанами Парку визначали за допомогою середніх коефіиієнтів переведення фітомаси в абсолютно сухому стані у вуглеиь (0,50 - для деревних фракиій та 0,45 - для листя і нижніх ярусів). Здійснено групування розрахунків середньої щільності фітомаси та вуглецю в деревостанах НПП «Голосіївський» за кварталами. Встановлено, що загалом деревостанами Парку нагромаджено 505,17 тис. т фітомаси, в якій депоновано 250,72 тис. т вуглеию. Середня щільнність фітомаси

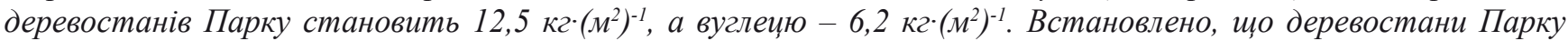
мають значний ресурсний потенціал, ефективне використання якого сприятиме вирішенню низки екологічних проблем регіону дослідження.

Ключові слова: біопродуктивність лісів; фітомаса; щільність фітомаси; депонований вуглець; деревостани Парку.

Вступ. У Києві, найбільшому із українським міст, швидкими темпами відбуваються процеси забудови, землевідведення під які часто можливі винятково за рахунок природних територій. Водночас Київ $є$ унікальною європейською столицею, на території якої вдалося зберегти цінні природні комплекси. Одним із найбільших лісових масивів на території столиці є Національний природний парк «Голосіївський» (НПП «Голосіївський»), деревостани якого виконують низку важливих екологічних функцій, але при цьому зазнають значного негативного антропогенного впливу. Дослідження лі- сової рослинності Парку та ï внеску в стабілізацію довкілля $є$ актуальними, потребують комплексного оцінювання іiї біотичної продуктивності, зокрема запасів фітомаси та депонованого в ній вуглецю.

В Україні значну кількість наукових праць присвячено дослідженню біопродуктивності лісових насаджень, але об'єктами досліджень рідко ставали природоохоронні об'єкти, які мають особливу екологічну, рекреаційну та наукову цінність. Дослідження біологічної продуктивності деревостанів у Національних природних парках України проведено для таких об'єктів: НПП «Сколівські

\footnotetext{
Лакида Петро Іванович - академік Лісівничої академії наук України, професор, доктор сільськогосподарських наук, директор Навчально-наукового Інституту лісового і садово-паркового господарства. Національний університет біоресурсів і природокористування України, вул. Героїв оборони, 15, м. Київ, 03041, Україна. Тел.: 044-527-85-28; +38-067-462-80-43. E-mail: lakyda@nubip.edu.ua

2 Дубровець Богдана Вікторівна - аспірант кафедри таксації лісу та лісового менеджменту Навчально-наукового Інституту лісового і садово-паркового господарства, Національний університет біоресурсів і природокористування України, вул. Героїв оборони, 15 , м. Київ, 03041, Україна. Тел.: 044-527-81-53; +38-097-019-65-56. E-mail: dana528@ukr.net
} 
Бескиди» (Lakyda \& Domashovets, 2009), Шацький НПП (Lakyda \& Sakharuk, 2013), Карпатський НПП (Lakyda \& Bokoch, 2015), НПП «Прип'ять-Стохід (Melnyk, 2015), ДО «Резиденція «Залісся» (Lakyda \& Vasylyshyn, 2016). Як засвідчив ретроспективний аналіз стану вивчення біопродуктивності лісів України, подібних досліджень на території НПП «Голосіївський» не здійснювали.

Об'єкти та методика дослідження. Об'єкт дослідження - лісова рослинність Національного природного парку «Голосіївський». Предмет дослідження - оцінка запасів фітомаси деревостанів та депонованого в них вуглецю. Мета дослідження здійснити окремо для кожного таксаційного виділу деревостанів НПП «Голосіївський» оцінку запасів фітомаси та депонованого в ній вуглецю та проаналізувати їх щільності.

Оцінювання нагромаджених запасів фітомаси та вуглецю у деревостанах Парку потребує використання інформації, яка отримана з тимчасових пробних площ, закладених безпосередньо у регіоні дослідження. Для вирішення завдань роботи за основу використано методику збору дослідних даних (Laky$\mathrm{da}, 2002)$. Для вирішення поставленої мети використано матеріали 52 тимчасових пробних площ, закладених у деревостанах головних лісотвірних порід, які домінують у лісостанах Парку (Dubrovets, 2016). Враховуючи природоохоронний статус об'єкта досліджень, тимчасові пробні площі було закладено у подібних типах лісорослинних умов інших лісогосподарських підприємств Київської області.

На основі отриманих даних про запаси фітомаси на тимчасових пробних площах було проведено моделювання показника конверсійного коефіцієнта головних лісотвірних порід Парку, який показує відношення маси фракції фітомаси до запасу стовбура у корі. Регресійні рівняння конверсійних коефіцієнтів розроблено для таких компонентів: деревина стовбурів без кори, кора стовбурів, деревина i кора гілок крони, листя або хвоя (Lakyda \& Dubrovets, 2017). Фітомасу для інших деревних порід, моделі для яких не розробляли, розраховували за моделями головних лісотвірних порід в межах групи порід. Оскільки під час дослідження біопродуктивності деревостанів Парку не вивчали фітомасу піднаметової рослинності та підземну фітомасу деревостанів, у роботі використано множинні регресійні рівняння конверсійних коефіцієнтів, отримані та апробовані авторами раніше (Lakyda, 2002).

Результати дослідження. На основі розроблених моделей конверсійних коефіцієнтів компонентів фітомаси головних лісотвірних порід Парку i повидільної бази даних лісовпорядкування на 01.01.2011 р. розраховано загальні обсяги фітомаси у деревостанах НПП «Голосіївський». За отриманими даними (табл.), деревостанами Парку загалом нагромаджено 505,17 тис. т фітомаси, в якій депоновано 250,72 тис. т вуглецю. Оскільки найбільшу частку за площею та запасом в Парку займають хвойні деревостани, відповідно і найбільші обсяги фітомаси та вуглецю нагромаджено саме в них.

У загальній структурі компонентів фітомаси частка деревини стовбура у корі становить $66,0 \%$, фітомаса крон - 8,0\%, 3 яких 5\% - деревина і кора гілок та $3 \%$ - листя і хвоя (рис. 1). Варто також зазначити, що структура компонентів фітомаси для окремих груп лісотвірних порід та деревних видів $€$ неоднорідною.

Загальна фітомаса та депонований у ній вуглець деревостанів НПП «Голосіївський»

Табличя

\begin{tabular}{lcccccc}
\hline \multirow{2}{*}{ Група порід } & \multirow{2}{*}{ Площа, га } & \multirow{2}{*}{ Запас, тис. м³ } & \multicolumn{2}{c}{ Фітомаса } & \multicolumn{2}{c}{ Вуглець } \\
\cline { 4 - 7 } & & & тис. т & щільність кг·( $\left.\mathrm{M}^{2}\right)^{-1}$ & тис. т & щільність кг $\left(\mathrm{м}^{2}\right)^{-1}$ \\
\hline Хвойні & 2566,57 & 689,10 & 346,79 & 13,5 & 171,79 & 6,7 \\
Твердолистяні & 1040,64 & 216,39 & 113,55 & 10,9 & 56,56 & 5,4 \\
М'яколистяні & 428,80 & 74,27 & 44,83 & 10,5 & 22,37 & 5,2 \\
Всього & 4036,01 & 979,76 & 505,17 & 12,5 & 250,72 & 6,2 \\
\hline
\end{tabular}

Найбільшу частку гілок та листя в загальній структурі компонентів фітомаси мають грабові деревостани (11,1 та 4,0\% відповідно). Значну частку у структурі фітомаси деревостанів Парку становить деревина стовбурів - від 59,0\% для граба звичайного до $64,3 \%$ для дуба звичайного.

Найбільшу частку кори мають вільхові деревостани, яка становить в середньому $12,8 \%$, що $є$ характерним для цього деревного виду (Lakyda \& Blyshchyk, 2015). Частка деревини та кори гілок $\epsilon$ найвищою у твердолистяних порід, а найнижчою - у м'яколистяних, що становить 6,0 та 2,8\% відповідно.

Щільність фітомаси $є$ важливим показником, який характеризує біопродуктивність насаджень на оди- ниці площі. Оскільки показник щільності фітомаси деревостанів істотно залежить від породного складу насадження, віку та продуктивності деревостанів, окрім загальної характеристики, доцільно також навести показники середньої щільності фітомаси деревостанів Парку в межах групи порід для Південної науково-дослідної ділянки (Південна НДД) та Північної науково-дослідної ділянки (Північна НДД), таксаційні характеристики деревостанів яких мають суттєві відмінності (рис. 2).

Отже, найпродуктивнішими $€$ хвойні деревостани Північної НДД, щільність фітомаси яких становить 16,0 кг·( $\left.\mathrm{M}^{2}\right)^{-1}$. Насадження твердолистяної групи порід мають вищу продуктивність у Південній НДД 
12,4 кг·(м²)-1, а м'яколистяної - у Північній НДД $\left(11,2 \kappa \Gamma \cdot\left(\mathrm{M}^{2}\right)^{-1}\right)$. Порівнюючи насадження південної та північної частин Парку, можна констатувати про вищу продуктивність деревостанів Південної НДД.

Середня щільність фітомаси деревостанів Парку становить 12,5 кг $\left(\mathrm{M}^{2}\right)^{-1}$, що $є$ значно нижче, ніж аналогічні показники для Київської області $\left(16,8\right.$ кг $\left.\left(\mathrm{M}^{2}\right)^{-1}\right)$ та для України загалом $\left(15,9\right.$ кг $\left.\cdot\left(\mathrm{M}^{2}\right)^{-1}\right)$ (Shvidenko et al., 2014).

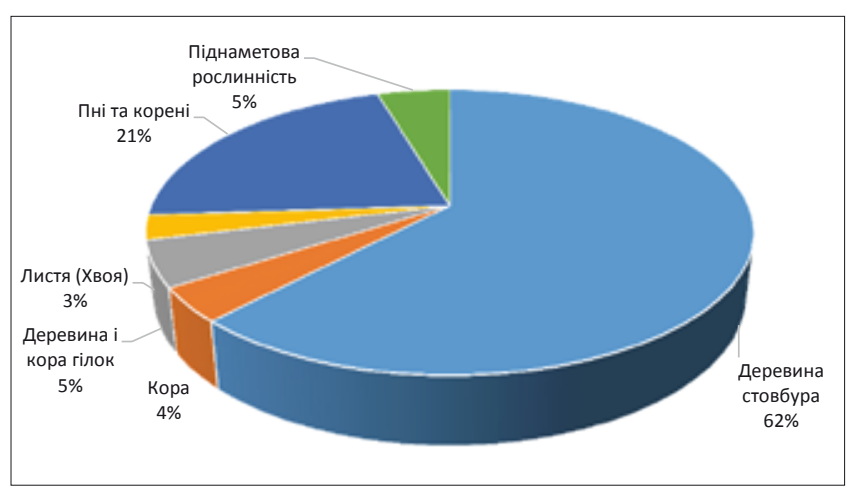

Рис. 1. Структура компонентів фітомаси деревостанів НПП «Голосіївський»

Важливим етапом під час дослідження біопродуктивності та екологічних функцій лісів Парку $є$ оцінювання вуглецедепонувальної функції окремо для кожного таксаційного виділу. Вміст депонованого вуглецю деревостанами Парку визначали за допомогою середніх коефіцієнтів переведення фітомаси в абсолютно сухому стані у вуглець, які $\epsilon$ довідковою інформацією та становлять 0,50 для деревних фракцій та 0,45 - для листя і нижніх ярусів. Окремо для кожного таксаційного виділу було вирахувано запас нагромадженого вуглецю та його щільність. Згруповані поквартально показники середньої щільності вуглецю депонованого деревостанами Парку наочно зображено на рис. 3.

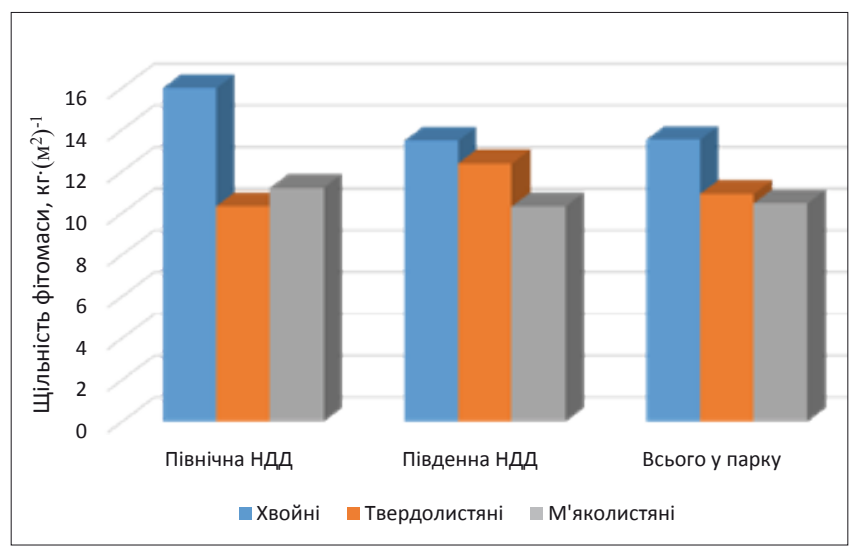

Рис. 2. Середня щільність фітомаси деревостанів НПП «Голосіївський»

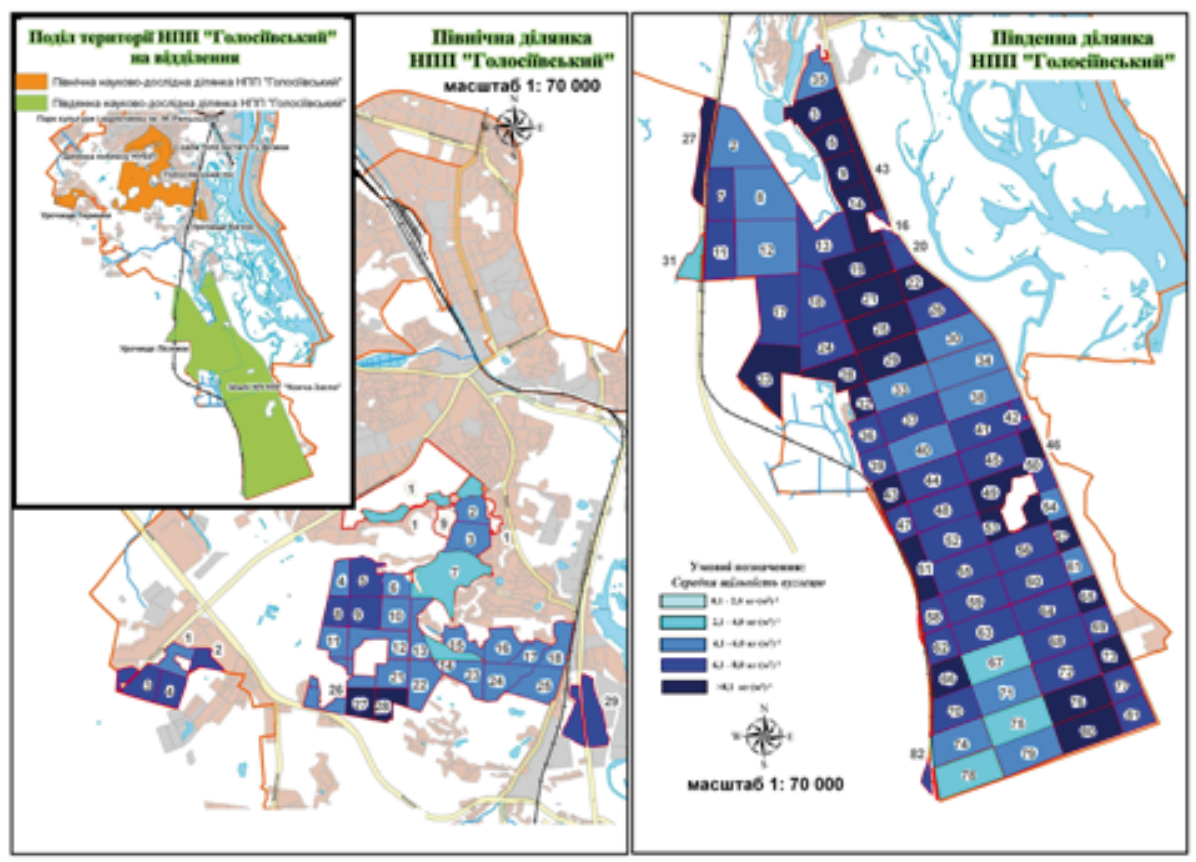

Рис. 3. Середня щільність вуглецю в деревостанах НПП «Голосіївський»

Обсяги та щільність фітомаси і депонованого в ній вуглецю $є$ похідною від мінливості значень основних таксаційних показників деревостанів. 3 віком у насадженнях зростає щільність фітомаси та акумульованого в ній вуглецю. Депонування вуглецю найактивніше відбувається в середньовікових деревостанах, частка яких становить $60,0 \%$ в Парку. Найвищий показник щільності вуглецю характерний для стиглих деревостанів усіх груп порід. У перести- глих насадженнях досліджуваний показник суттєво зменшується, що пов'язано з початком деструктивних процесів.

Висновки. Загальна площа вкритих лісовою рослинністю ділянок НПП «Голосіївський» на 2010 р. становить 4036,01 га зі стовбуровим запасом 979,76 тис. м³. Деревостанами Парку нагромаджено 505,17 тис. т фітомаси, в якій акумульовано 250,72 тис. т вуглецю. Найбільший обсяг фітомаси 
нагромаджено хвойними деревостанами 68,6 \%, значно менше - твердолистяними та м'яколистяними (22,5 та 8,9\% відповідно).

Середня щільність фітомаси деревостанів Парку становить 12,5 кг·( $\left.\mathrm{M}^{2}\right)^{-1}$, при цьому найвище значення показника характерне для хвойних деревостанів Парку $\left.\left(13,5 \text { кг'( } \mathrm{M}^{2}\right)^{-1}\right)$. Середній показник щільності вуглецю деревостанів НПП «Голосіївський» становить 6,2 кг'( $\left(\mathrm{M}^{2}\right)^{-1}$, що є значно нижче, ніж аналогічні показники для Київської області

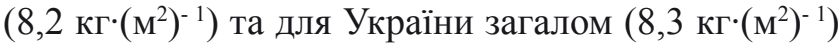
(Shvidenko et al., 2014).

Комплексна оцінка біологічної продуктивності лісів НПП «Голосіївський» за компонентами фітомаси сприятиме вирішенню низки питань, пов'язаних 3 пошуком додаткових джерел депонування вуглецю, підвищення продуктивності лісів та поліпшення загального екологічного стану навколишнього природного середовища, адже ліси Парку виконують важливу роль у стабілізації довкілля Києва та його околиць.

\section{Бібліографічні посилання}

Dubrovets, B. V. (2016). Experimental base of empirical data for the bioproductivity assessment of NNP «Holosiivskyi». Scientific Bulletin of the National University of Life and Environmental Sciences of Ukraine. Series: Arboriculture and ornamental horticulture, 255, 46-53 (In Ukrainian).

Lakyda, M. A. (2017). Biotic productivity of State organization "Residence» Zalissya»: current state and dynamics (Doctoral dissertation, Ukrainian National Forestry University, Lviv, Ukraine). Thesis for a scientific degree of Candidate in Agricultural Sciences, specialty 06.03.02 «Forest mensuration and forest inventory». Lviv: UNFU (In Ukrainian). Retrieved from http://nltu.edu. ua/index.php?option $=$ com_content\&view $=$ artic le\&id=1614:2017-05-29-0 $\overline{5}-34-43 \&$ catid=115:$3507202 \&$ Itemid $=357$

Lakyda, P. I., \& Domashovets, G. S. (2009). Bioproductivity of the forests of Lviv region and its dynamics. Korsun-Shevchenkivsky: FOP Maydachenko, I.S. (In Ukrainian).

Lakyda, P. I., \& Dubrovets, B. V. (2017). The models of conversion coefficients of tree stands phytomas's components of NNP «Holosiivskyi». Scientific Bulletin of the National University of Life and Environmental Sciences of Ukraine. Series: Arboriculture and ornamental horticulture, 278, 48-57 (In Ukrainian).

Lakyda, P. I., \& Sakharuk, G. A. (2013). Bioproductivity of the forests of the Shatsk National natural park. Korsun-Shevchenkivsky: FOP Havryshenko, V.M. (In Ukrainian).

Lakyda, P. I. (2002). Phytomass of Forests of Ukraine. Ternopil: Zbruch (In Ukrainian).

Lakyda, P. I., Blyschyk, V. I., \& Blyschyk, I. V. (2017). Primary production of alder forests of the Ukrainian polissya. Korsun-Shevchenkivsky: FOP Havryshenko, V.M. (In Ukrainian).
Lakyda, P. I., Bococh, V. V., Vasylyshin, R. D. \& Terentyev, A. Y. (2015). Bioproductivity of forests phytocoenoses of the Kapaty National natural park. Korsun-Shevchenkivskyi: FOP Havryshenko, V.M. (In Ukrainian).

Melnyk, O.M. (2017). Bioproductivity and ecological potential of forests of the national natural park «Pripyat-Stohid». Thesis for a scientific degree of candidate in agricultural sciences, specialty 06.03.02 «Forest mensuration and forest inventory». Kyiv (In Ukrainian).

Shvidenko, A. Z. et al. (2014). Carbon, climate, and land-use in Ukraine: Forest sector. Korsun-Shevchenkivskyi: FOP Havryshenko, V.M. (In Ukrainian).

\section{Биотическая продуктивность лесов Национального природного парка «Голосеевский»}

\section{П.І. Лакида' , Б. В. Дубровець²}

По результатам проведенных исследований представлена структура и общие объемы фитомассы и депонированного в ней углерода древостоев Национального природного парка «Голосеевский». Расчет биотической производительности древостоев Парка проведен отдельно для каждого таксационного участка на основе базы данных лесоустройства по состоянию на 2010 г., которая содержит данные 1866 участков. При расчете объемов фитомассы древостоев парка использованы разработанные ранее регрессионные уравнения конверсионных коэффициентов, связывающих фитомассу насаждений по фракциям с таксационными показателями для таких древесных видов, как: сосна обыкновенная, дуб обыкновенный, граб обыкновенный и ольха. Содержание депонированного углерода древостоями парка определено с помощью средних коэффициентов перевода фитомассы в абсолютно сухом состоянии в углерод $(0,50$ для древесных фракций и 0,45 для листьев и нижних ярусов). Проведена группировка расчетов средней плотности фитомассы и углерода в древостоях НПП «Голосеевский» по кварталам.

Общая площадь покрытых лесной растительностью участков НПП «Голосеевский» по состоянию на 2010 г. составляет 4036,01 га со

\footnotetext{
Лакида Петро Іванович - академик Лесной академии наук Украины, профессор, доктор сельскохозяйственных наук, директор Учебно-научного института лесного и садовопаркового хозяйства, Национальный университет биоресурсов и природопользования Украины, ул. Героев обороны, 15 , г. Киев, 03041, Украина. Тел.: 044-527-85-28; +38-067-462-8043. E-mail: lakyda@nubip.edu.ua

Дубровеиь Богдана Вікторівна - аспирант кафедры таксации леса и лесного менеджмента Учебно-научного института лесного и садово-паркового хозяйства, Национальный университет биоресурсов и природопользования Украины, ул. Героев обороны, 15, г. Киев, 03041, Украина. Тел.: 044-527-81-53; +38097-019-65-56. E-mail: dana528@ukr.net
} 


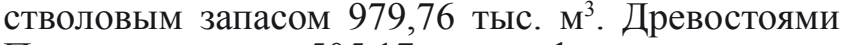
Парка накоплено 505,17 тыс. т фитомассы, в которой аккумулировано 250,72 тыс. т углерода. Наибольший объем фитомассы накоплен хвойными древостоями - 68,6\%, значительно меньше твердолиственными и мягколиственными (22,5 и $8,9 \%$ соответственно).

В общей структуре компонентов фитомассы долевое участие древесины ствола в коре составляет $66,0 \%$, фитомассы крон - 8,0\%, из которых 5,2\% древесина и кора ветвей и 2,8\% - листья и хвоя. Стоит также отметить, что структура компонентов фитомассы для отдельных групп лесообразующих пород и древесных видов является неоднородной. Долевое участие древесины и коры ветвей является самой высокой у твердолиственных пород, а самой низкой - в мягколиственных, что составляет 6,0 и $2,8 \%$ соответственно.

Средняя плотность фитомассы древостоев в Парке составляет 12,5 кг $\cdot\left(\mathrm{M}^{2}\right)^{-1}$, при этом высокое значение показателя характерно для хвойных древостоев $\left(13,5\right.$ кг $\left.\cdot\left(\mathrm{M}^{2}\right)^{-1}\right)$. Средний показатель плотности углерода древостоев НПП «Голосеевский» составляет 6,2 кг $\cdot\left(\mathrm{M}^{2}\right)^{-1}$, что значительно ниже, чем аналогичные показатели для Киевской области $\left(8,2\right.$ кг $\left.\cdot\left(\mathrm{M}^{2}\right)^{-1}\right)$ и для Украины в целом $\left(8,3\right.$ кг $\left.\cdot\left(\mathrm{M}^{2}\right)^{-1}\right)$.

Комплексная оценка биологической продуктивности лесов НПП «Голосеевский» по компонентам фитомассы будет способствовать решению ряда вопросов, связанных с поиском дополнительных источников депонирования углерода, повышение продуктивности лесов и улучшение общего экологического состояния окружающей среды, ведь леса Парка выполняют важную роль в стабилизации окружающей среды Киева и его окрестностей.

Ключевые слова: биопродуктивность лесов; фитомасса; плотность фитомассы; депонированный углерод; древостои Парка.

\section{Biotic productivity of forests of the National Natural Park «Holosiivskyi»}

\section{P. Lakyda' ${ }^{1}$ B. Dubrovets ${ }^{2}$}

According to the research results, the structure and total volumes of phytomass and sequestered carbon of

Petro Lakyda - full Member of Forestry Academy of Sciences of Ukraine, Professor, Doctor of Agricultural Sciences, Director of Education and Research Institute of Forestry and LandscapePark Management. National University of Life and Environmental Sciences of Ukraine, Heroyiv Oborony st., 15, Kyiv, 03041, Ukraine. Tel.: 044-527-85-28; +38-067-462-80-43. E-mail: lakyda@nubip.edu.ua

Bohdana Dubrovets - Phd student of the department of forest inventory and forest management of Education and Research Institute of Forestry and Landscape-Park Management. National University of Life and Environmental Sciences of Ukraine, Heroyiv Oborony st., 15, Kyiv, 03041, Ukraine. Tel.: 044-527-81-53; +38097-019-65-56. E-mail: dana528@ukr.net the National natural park «Holosiivskyi» forest stands are presented. The calculation of the biotic productivity of park forest stands was conducted separately for every 1866 stands using the data of forest inventory as of 2010. For calculating the volumes of phytomass of NPP «Holosiivskyi» forest stands, previously developed regression equations of biomass expansion factors were used. These equations were developed created for park's main tree species: pine, oak, hornbeam, and alder. Using conversion factors $(0.5$ for wood and bark and 0.45 for leaves and understory vegetation) which were applied to live biomass stock in a bone-dry state, the total stock of sequestered carbon was calculated. The results of calculations of the average density of phytomass and carbon calculations in the NPP «Holosiivskyi» tree stands were grouped by compartments.

The total area covered with forest vegetation of the National natural park «Holosiivskyi» in 2010 was 4036.01 ha with a total volume of growing stock 979.76 thousand $\mathrm{m}^{3}$. The Park's tree stands has accumulated 505.17 thousand tons of live biomass, in which 250.72 thousand tons of carbon are sequestered. The largest amount of live biomass is accumulated by coniferous tree stands $(68.6 \%)$, much less by hardwood and softwood (22.5\% and $8.9 \%$, respectively).

In the total structure of the components of live biomass, the share portion of trunk with bark is $66.0 \%$, live biomass of crowns $-8.0 \%$, of which $5.2 \%$ are wood and bark of branches and $2.8 \%$ are leaves and needles. The structure of the phytomass components for individual groups of forest-forming species and tree species is different. The share portion of branches is the highest in hardwood, and the lowest - in softwood, which is $6.0 \%$ and $2.8 \%$, respectively.

The average density of live biomass of the tree stands in the Park is $12.5 \mathrm{~kg} \cdot\left(\mathrm{m}^{2}\right)^{-1}$, while a high value is typical for coniferous forest stands $\left(13.5 \mathrm{~kg} \cdot\left(\mathrm{m}^{2}\right)^{-1}\right)$. The average carbon density of the National natural park «Holosiivskyi» tree stands is $6.2 \mathrm{~kg} \cdot\left(\mathrm{m}^{2}\right)^{-1}$, which is significantly lower than the similar indicators for the Kyiv region $\left(8.2 \mathrm{~kg} \cdot\left(\mathrm{m}^{2}\right)^{-1}\right)$ and for Ukraine as a whole $\left(8.3 \mathrm{~kg} \cdot\left(\mathrm{m}^{2}\right)^{-1}\right)$.

The forests of the Park play an important role in stabilizing the environment in Kyiv and its surroundings. Comprehensive assessment of the biological productivity of the National natural park «Holosiivskyi» tree stands will contribute to solving a range number of environmental problems in the research region of research.

Key words: bioproductivity of forests; density of phytomass; sequestered carbon; park forest stands. 